\title{
Cyanobacterial and algal diversity in the vicinity of two different seabird colonies in Spitsbergen
}

\author{
Mirosława PIETRYKA ${ }^{1}$, Dorota RICHTER ${ }^{1}$ and Jan MATUŁA ${ }^{2}$ \\ ${ }^{1}$ Katedra Botaniki i Ekologii Roślin, Uniwersytet Przyrodniczy we Wrocławiu, \\ pl. Grunwaldzki 24a, 50-363 Wrocław, Poland \\ <miroslawa.pietryka@up.wroc.pl>,<dorota.richter@up.wroc.pl> \\ 2 Instytut Biologii, Uniwersytet Przyrodniczy we Wrocławiu, \\ ul. Kożuchowska 5B, 51-631 Wrocław, Poland \\ $<j a n . m a t u l a @ u p . w r o c . p l>$
}

\begin{abstract}
The aim of the study was to compare cyanobacterial and algal assemblages occurring in ornithocoprophilous habitats formed under the influence of two seabird colonies (mixed colony of piscivorous Uria lomvia and Rissa tridactyla and planktivorous Alle alle) nesting on the southwest side of Hornsund (Spitsbergen). Various influences of the bird colonies (e.g. surface trophy, treading) lead to the formation of ornithogenic habitats with quantitatively and qualitatively diverse cyanobacterial and algal assemblages. Only 6 species common to both habitats were identified, but due to their different proportions the similarity ended there. Cyanobacterial and algal assemblages of both ornithogenic habitats also react rather differently to the intensity of the bird colonies' influence. The assemblages located directly beneath piscivorous bird nests were characterized by a larger number of species, which decreased the farther from the colony it was. Cyanobacterial and algal assemblages located directly next to planktivorous bird nests were species poor, but species richness increased at locations farther from their direct influence. The obtained results confirmed that bird colonies characterized by different diet and behavior influenced the formation of two separate, quantitatively and qualitatively different cyanobacterial and algal assemblages. Species such as Eucapsis sp., Gleocapsopsis sp., Gloeothece sp., Woronichinia sp., Hematococcus sp. were characteristic for algae and cyanobacteria assemblages in the vicinity of piscivorous bird colonies, whereas Aphanocapsa sp., Gloeothece sp., Komvophoron minutum, Pseudanabaena sp., Gloeocystis sp. 2 occurred in the vicinity of planktivorous bird colonies.
\end{abstract}

Key words: Arctic, Spitsbergen, cyanobacterial and algal assembalges, influence of seabirds, trophy. 


\section{Introduction}

Some aspects of polar research are focused on vegetation (vascular plant communities; mosses, cyanobacterial and algal assemblages) formed as a result of nesting bird colonies enriching these ecosystems in nutrients (Stempniewicz et al. 2006, 2007; Smykla et al. 2007; Zmudczyńska et al. 2012). Polar habitats are characterized by a deficiency of nutrients such as nitrogen, potassium and calcium (Lindeboom 1984; Odasz 1994; Stempniewicz 2005) and, consequently, every change in nutrient level visibly influences the vegetation.

Birds obtaining nutrients as food from the sea introduce them into the ecosystem, leaving food remains, feathers and eggs, and depositing large amounts of guano near the colonies (Stempniewicz 1990; Godzik 1991; Stempniewicz and Węsławski 1992; Anderson and Polis 1999; Tatur 2002; Ligęza and Smal 2003; Hawke and Newman 2004; Breuning-Madsen et al. 2008; Mulder et al. 2011; Zwolicki et al. 2013). The quantity of nutrients introduced by bird colonies into polar ecosystems low in nutrients is higher than from other sources, such as precipitation, sea spray or nitrogen assimilated from heterocytous cyanobacteria (Erskine et al. 1998; Bokhorst et al. 2007; Skrzypek et al. 2015). Decomposition by soil microorganisms releases nutrients into circulation, and they may be assimilated by producers (Ryan and Watkins 1989; Cragg and Bardgett 2001; Hodkinson et al. 2002; Smith and Froneman 2008). Habitats formed in this way and rich in nutrients provide conditions for the growth of eutrophic vegetation but may also limit the development of species which prefer less rich habitats. Depending on requirements, tolerance and adaptation capabilities, species richness and plant community coverage (including cyanobacterial and algal assemblages) change (Theodose and Bowman 1997; Pennings et al. 2005; Zelenskaya and Khoreva 2006; Smykla et al. 2007). That way ornithocoprophilous habitats characterized by particular cyanobacterial and algal assemblages, mosses and vascular plant communities form in the range of nesting birds (Hogg and Morton 1983; Myrcha and Tatur 1991; Elvebakk 1994; Matuła et al. 2007; Jakubas et al. 2008; Richter et al. 2009, 2014, 2015; Zwolicki et al. 2015).

In the Svalbard region, on the Hornsund Fiord, there are two big bird colonies. On the coastal Gnålberget cliff there is a mixed colony of two piscivorous bird species - Brünnisch's guillemot (Uria lomvia L.) and black-legged kittiwake (Rissa tridactyla L.). On the Ariekammen slope, further from the coast, there is a colony of planktivorous little auk (Alle alle L.). Their diet and behavior influence the ornithocoprophilous habitats forming nearby. They are shaped by the direct influence of birds (treading) and nutrients (their quantity and quality) provided by birds through guano and food remains. Among them, nitrogen and phosphorus are the most significant for the diversity of habitats as to their trophy. The excrement of piscivorous Uria lomvia and Rissa tridactyla are rich 
in phosphorus as a result of this element's high content in fish bones. Studies conducted in the area confirmed that, consequently, there is a high content of phosphorus in the soil in the direct vicinity of the colonies. On the other hand, around the colony of the planktivorous Alle alle there was a high content of nitrate nitrogen (Zwolnicki 2013; Ziółek and Melke 2014).

Therefore, we may assume that two separate ornithogenic habitats will develop under the influence of two seabird colonies with different diet and behaviour. Since the most common and sometimes only components of polar tundra are cyanobacteria and algae, and since they are communities with the quickest reaction to changes in soil trophy (Davey and Rothery 1992; Kaštovska et al. 2005; Lan et al. 2013), the aim of the research was to compare two cyanobacterial and algal assemblages occurring in ornithocoprophilous habitats formed under the influence of piscivorous and planktivorous seabird colonies.

\section{Study area}

The research was carried out at the foot of the Gnålberget cliff of Hornsund area and on the Ariekammen mountain slope (West Spitsbergen, Svalbard Archipelago). The locations chosen for the study were situated in ornithocoprophilous habitats, characterized by long periods of dryness and strong sun exposure in summer. Within the soil habitats 10 sites were nominated for phycological research (Fig. 1).

The area with sites 1-5 was located at the foot of the Gnålberget rocky cliff (Fig. 2A) and was under the influence of mixed nesting colonies of two piscivorous seabird species - guillemots (Uria lomvia) and black-legged kittiwake (Rissa tridactyla) - located at the altitude of 500-400 m, with slope inclination of $45-50^{\circ}\left(77^{\circ} 02^{\prime} \mathrm{N}, 015^{\circ} 91^{\prime} \mathrm{E}\right)$.

Sites 1-2 were located directly under a seabird colony. The soil was highly dried, covered with the crumbled remains of plant material from birds' nests, without vascular plants and with only Prasiola crispa thalli.

Sites 3-5 were located slightly lower than the previous ones and were under lesser influence of the colonies. The soil was covered with a Cochlearia groenlandica - Poa alpina community, macroscopic Prasiola crispa thalli and cyanobacteria crusts.

The area with sites 6-10 was located on Ariekammen slope (Fig. 2B), under the influence of planktivorous seabird colonies of little auks (Alle alle), located at the altitude of $200-100 \mathrm{~m}$, slope inclination $35-40^{\circ}$ (latitude $77^{\circ} 00^{\prime} 36.8^{\prime \prime}-$ $77^{\circ} 00$ '35.9" $\mathrm{N}$, longitude $015^{\circ} 31^{\prime} 2^{\prime \prime}-015^{\circ} 31^{\prime} 7^{\prime \prime} \mathrm{E}$ ).

Sites 6-8 were located directly next to the colony. The surface was dried out, trodden by birds, covered with guano, food remains and feathers. The 


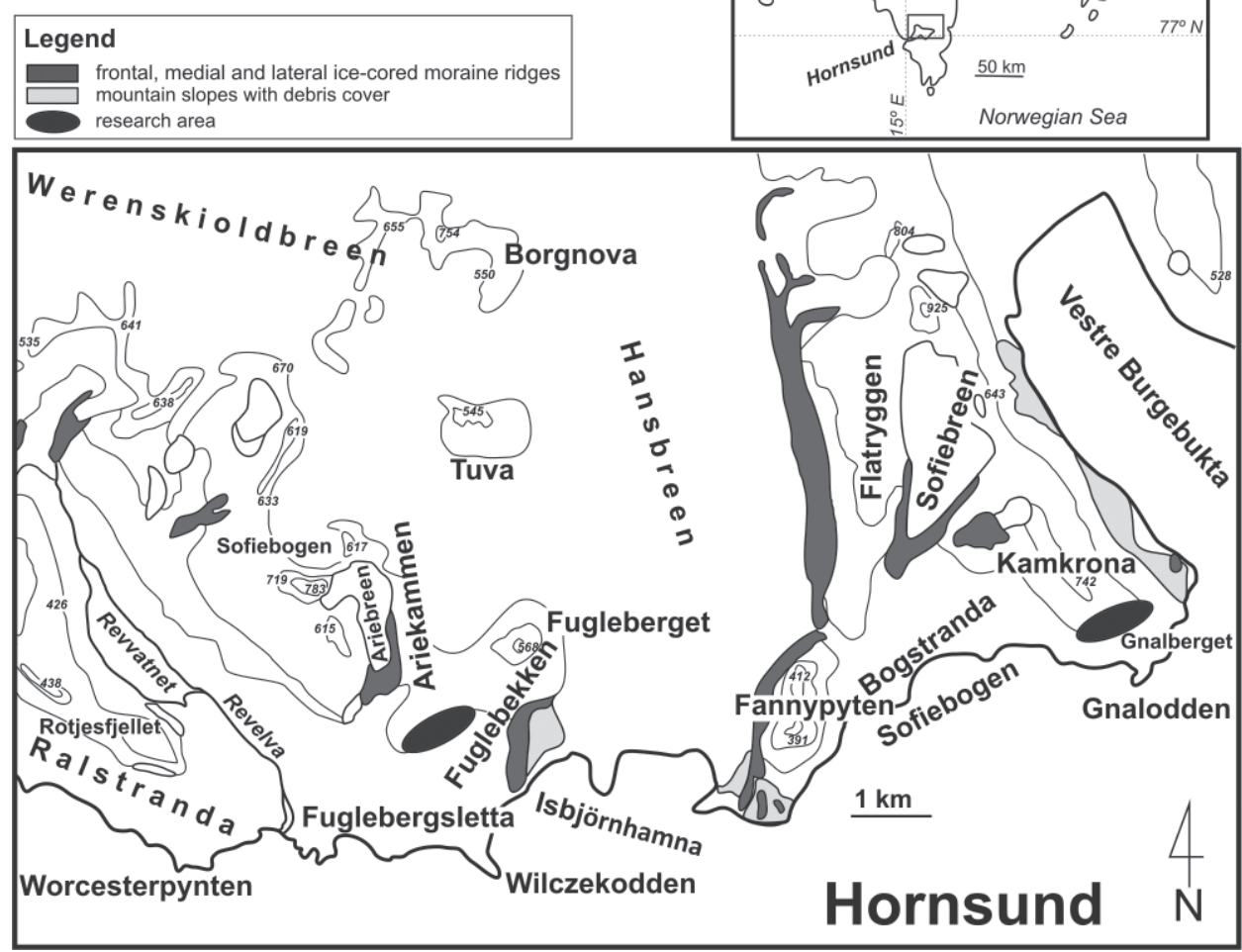

Fig. 1. A. Location of the Hornsund fjord; B. Location of the sites from where the samples were taken; black ovals show the ornithocoprophilous habitats.

soil was covered with a Prasiola crispa community and a small proportion of mosses (mainly as dead remains).

Sites 9-10 were located farther from the bird colony. They had a dry surface with visibly diverse vegetation, particularly Chrysosplenium tetrandrum - Cochlearia groenlandica communities and clumps of mosses with Poa alpina var. vivipara, Cerastium arcticum, Salix polaris and small thalli of Prasiola crispa. 


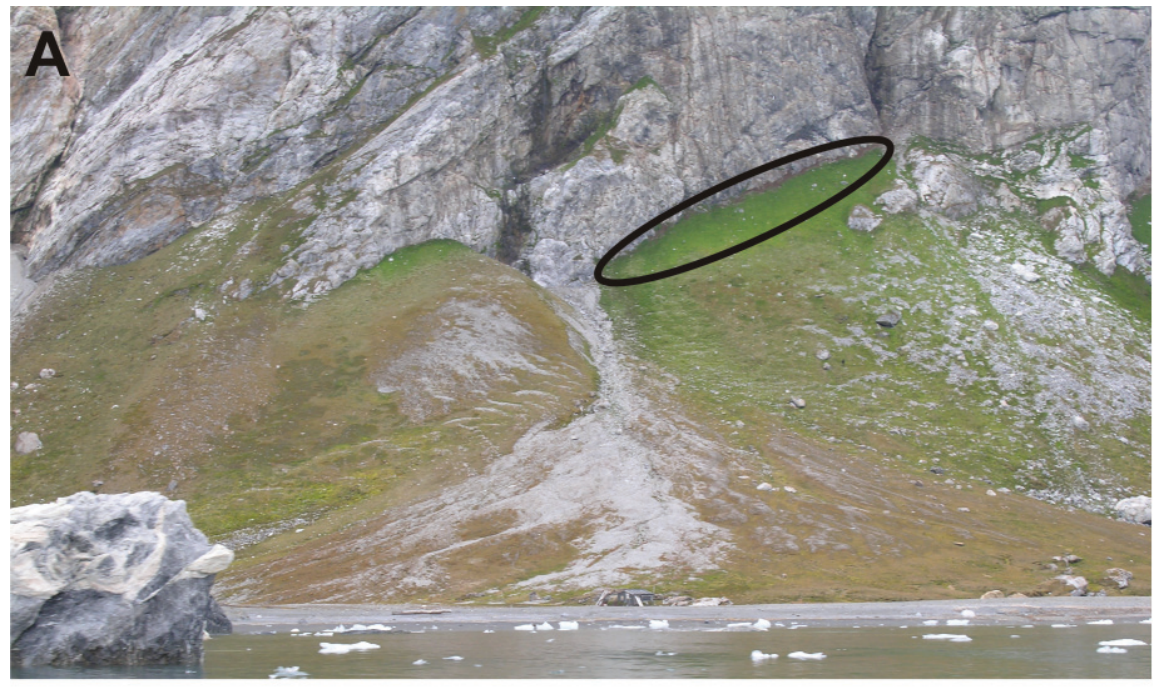

\section{B}

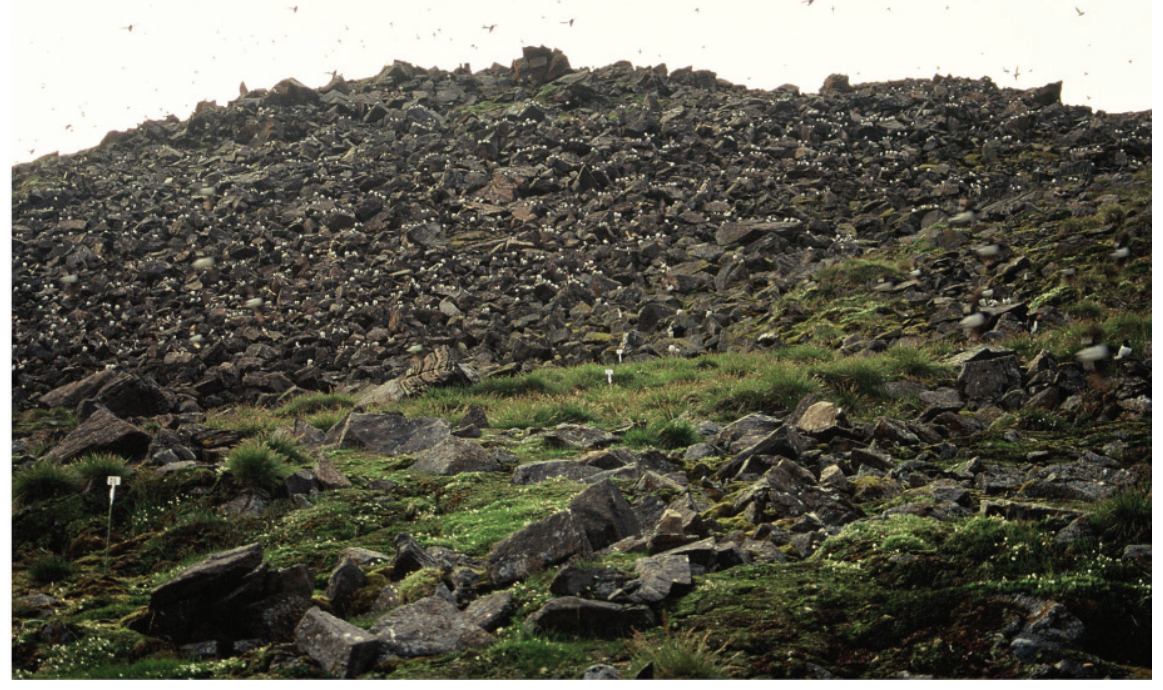

Fig 2. Study area: A. Gnålberget rocky cliff, B. Ariekammen slope.

\section{Materials and methods}

Research was conducted during the Arctic summer in July and August in the years 2009-2013. Samples were collected from soil surface and dead plant remains, between the moss turf mosaic and vascular plants, from a surface of $20 \mathrm{~cm}^{2}$ from all habitats in four repetitions. 
Species observations were conducted with a Nikon Eclipse TE2000-S light digital microscope. The taxon was digitally archived using the NIS image analysis program, which enables one to save the images with the proper scale of objects. The identification was performed live and also on material preserved. The abundance of particular species was estimated on a 5-degree scale (Table 1). Taxonomic classification was done according to Hoek et al. (1995). The names of species were updated according to detailed literature on the species (Komárek 2016).

The statistical analyses were performed using the following programs: MVSP 3.1 (Kovach 1985-1999), CANOCO 4.5 (Braak, Šmilauer 2002) and STATISTICA v. 12 package (StatSoft Inc. 2014). Shannon's diversity index (Shannon and Weaver 1949) was used to describe species diversity and evenness. In order to estimate the similarity of habitats with regard to phycoflora diversity we used numerical analysis including hierarchical-accumulative classification. In order to estimate the degree of phycoflora similarity between the habitats, Cosine Theta analysis was used. In order to arrange the samples according to their species composition, the ordination method was used. The calculated gradient of analyzed data was over $2 \mathrm{SD}$, which confirms the presence of unimodal data, hence the use of detrended correspondence analysis (DCA).

\section{Results}

Taxonomic characteristics of cyanobacterial and algal assemblages in the research areas. - A total of 55 cyanobacterial and algal species were identified in the studied area; 31 species occurred in habitats located on the Gnålberget cliff (14 coccoid or colonial cyanobacteria, 11 filaments without heterocytes, 1 heterocytous type and 5 species of Chlorophyta) and 28 species on the Ariekammen slope (5 coccoid or colonial cyanobacteria, 14 filaments without heterocytes, 1 heterocytous type and 8 species of Chlorophyta). The quantity and species composition of particular cyanobacterial and algal groups, as well as the quantity of particular species in the habitat, differed significantly in the studied ornithocoprophilous habitat types (Table 1).

At the foot of the Gnålberget cliff, in a location under the influence of piscivorous birds, the highest number of species was found at sites 1-2 (24 species, of which half were coccoid cyanobacteria). The dominating species was Prasiola crispa, which formed crusty thalli covering up to 50\% of the studied area's soil. It was numerously accompanied by the following cyanobacteria: Phormidium autumnale, Pseudanabaena frigida, Merismopedia sp., Gleocapsopsis sp., Eucapsis sp. and Cyanosarcina sp. Other species occurred in small quantities but were significant for the character of the habitat's phycoflora (Coccomyxa sp., Gloeocapsa punctata, Oscillatoria tenuis, Synechocystis sp.). 
$\frac{0}{0}$

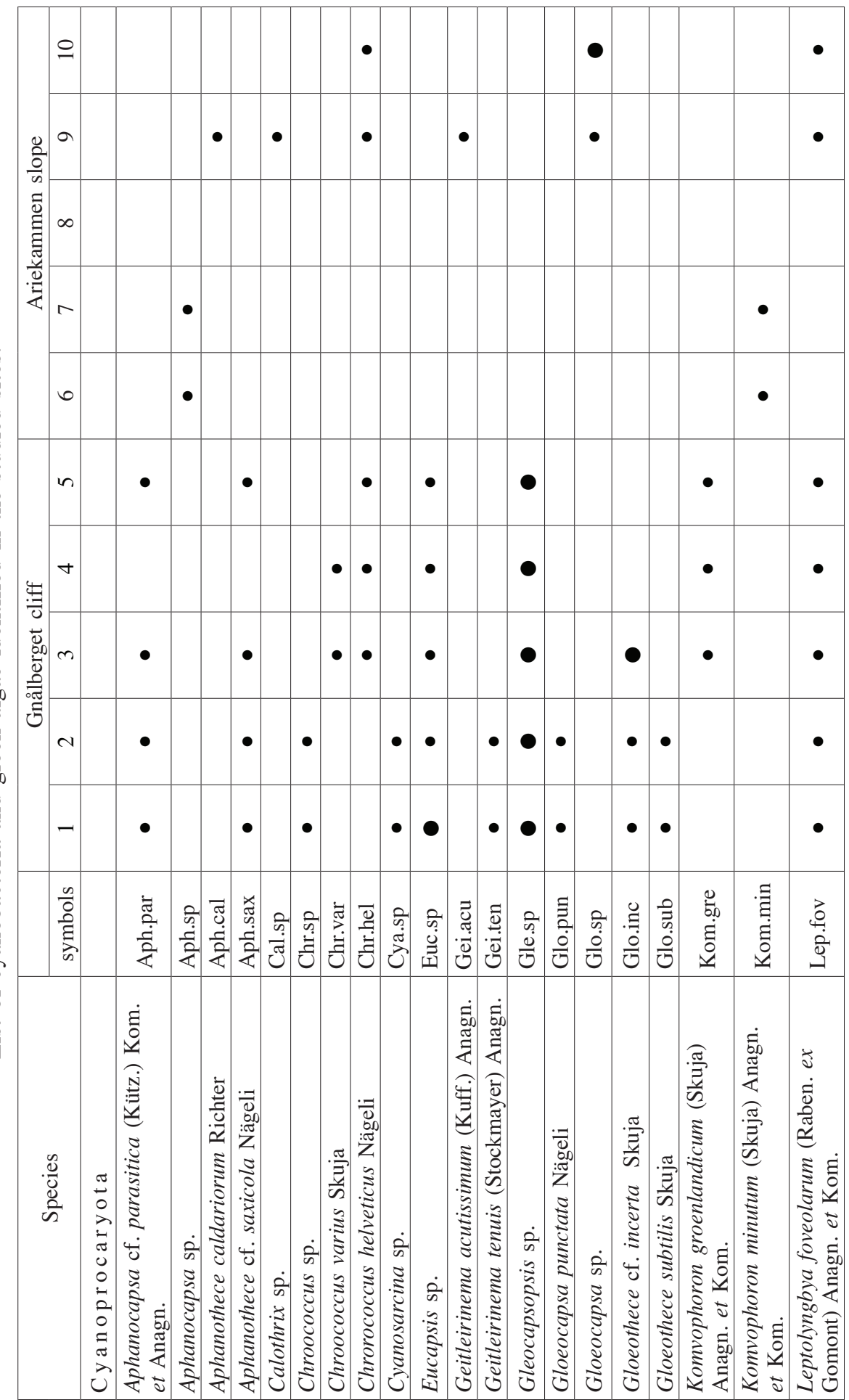




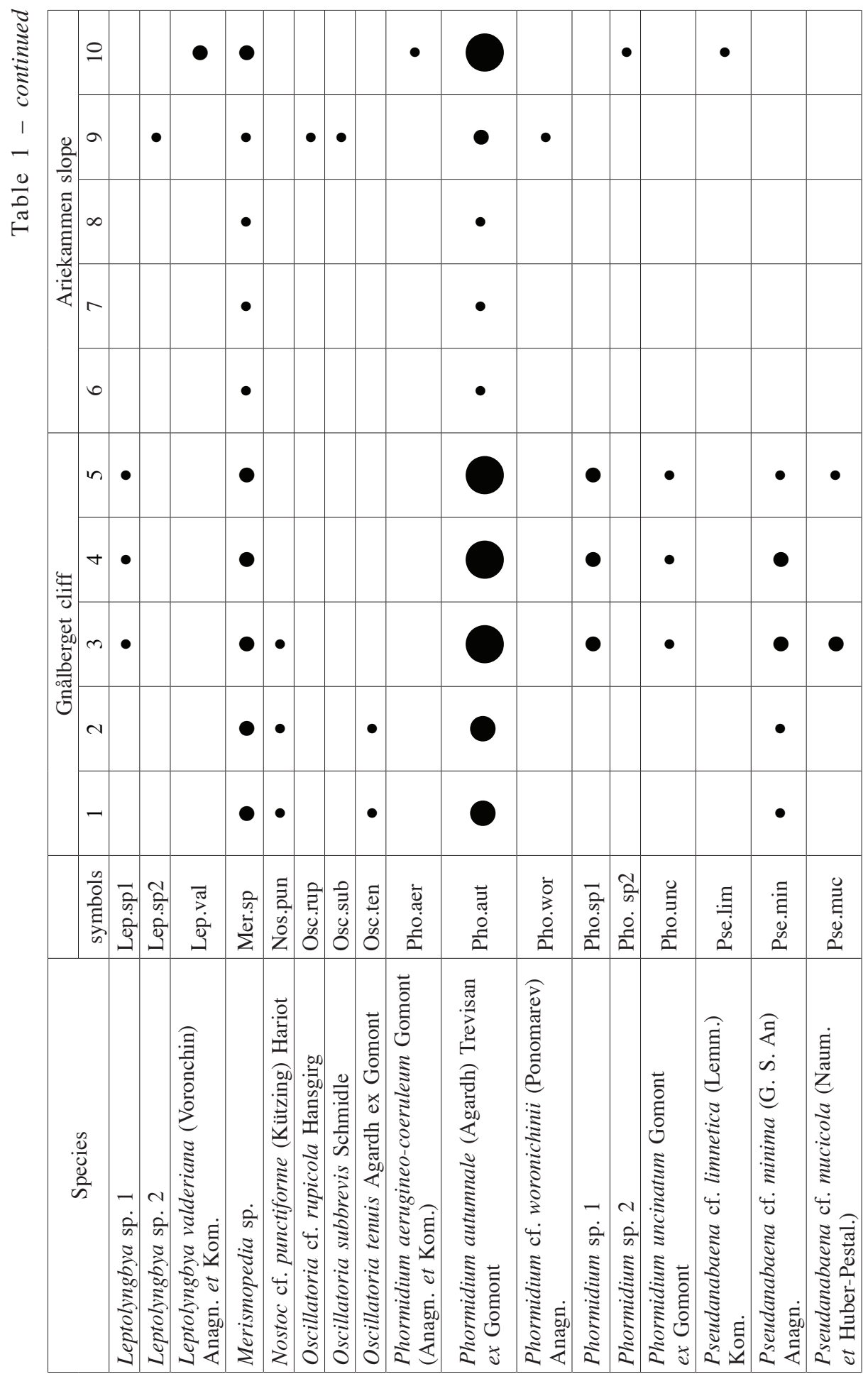




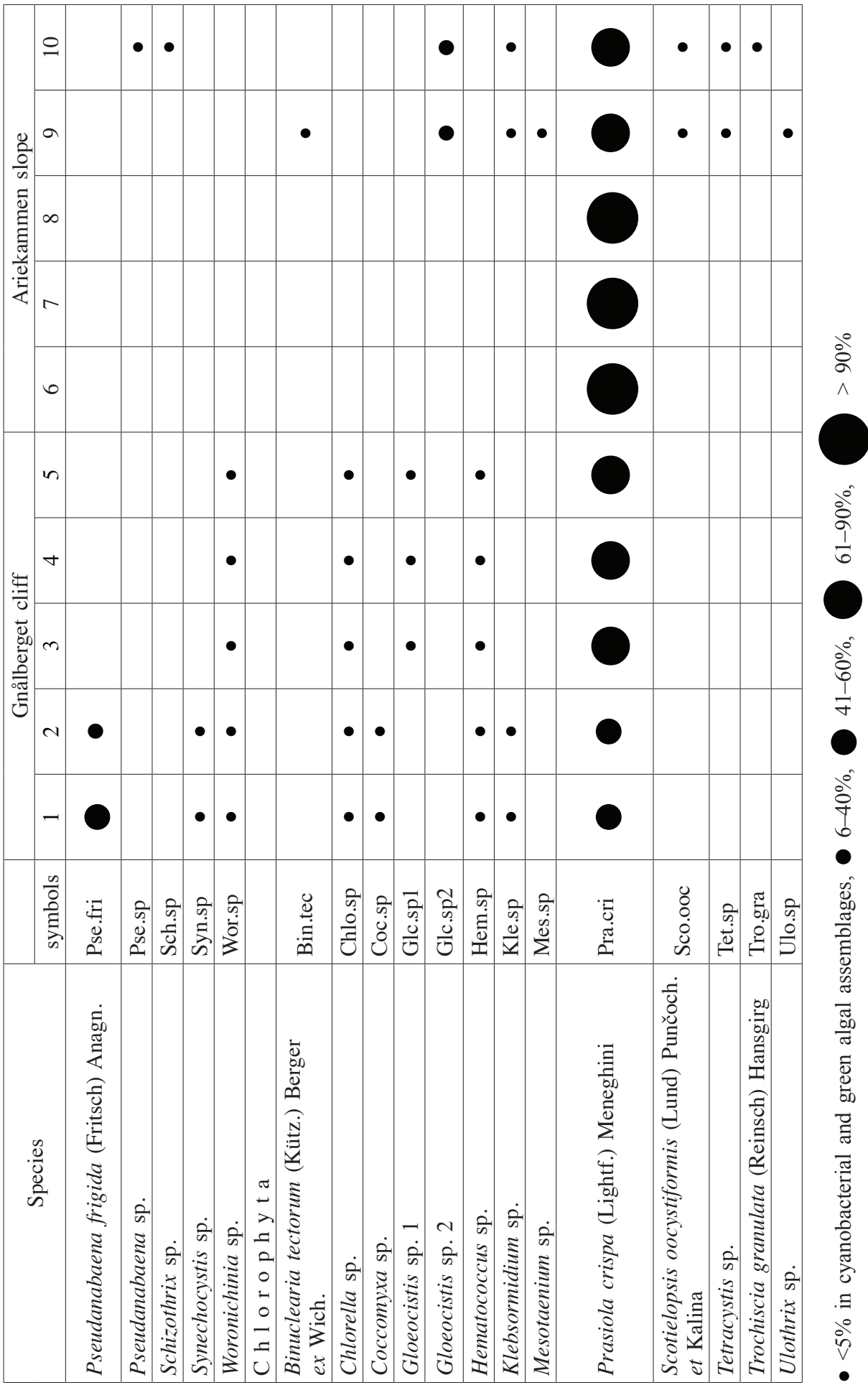


At sites 3-5, further away from the colony, the study revealed a larger proportion $(75 \%)$ of $P$. crispa in an assemblage which formed monostromatic green thalli. In the case of Phormidium autumnale there was also a larger proportion in the assemblage. The phycoflora was also characterized by the occurrence of species such as Gloeocapsopsis sp., Merismopedia sp., Pseudanabaena cf. minima, Pseudanabaena cf. mucicola, Leptolyngbya foveolarum, Woronichinia sp., Chloorococcus helvetius, Ch. varius, Phormidium sp. 1, P. uncinatum.

The analyses of phycoflora in the locations under the influence of planktivorous bird colonies also revealed the dominance of Prasiola crispa. At sites 6-8 (located within the bird colonies' influence) it covered 100\% of the surface. It formed macroscopic, green cracked thalli. Cyanobacterial and algal assemblages were not rich in species and only had 3-5 taxa (Aphanocapsa sp., Merismopedia sp., Komvophoron minutum, Phormidium autumnale, Prasiola crispa).

At sites 9-10 there was a rapid growth in the quantity of species (17-20), particularly with regard to filamentous cyanobacteria (7-8 taxa), mostly of Leptolyngbya, Phormidium, Oscillatoria genera. These habitats were also distinguished by the presence of such cyanobacteria as Gloeocystis sp. 2, Scotielopsis oocystiformis, Tetracystis sp., and Trochiscia granulata.

Diversity and evenness characteristics of cyanobacterial and algal assemblages in the research areas. - At the sites located on the Gnålberget cliff the Shannon-Weaver diversity index ( $\left.H^{\prime}\right)$ was 1.084 . The high value of the biodiversity index results, above all, from the evenness of proportions of the occurring species. This is also confirmed by the high value of the evenness index $(\mathrm{J})-0.963$ - suggesting that despite the quantitative dominance of Prasiola crispa, all species influence the shaping of assemblages in habitats under the influence of piscivorous birds (Uria lomvia, Rissa tridactyla).

At the sites located on the Ariekammen slope the diversity and evenness indices have much lower values. In habitats under the influence of planktivorous bird colonies (Alle alle) they are respectively $0.33(\mathrm{H})$ and $0.36(\mathrm{~J})$. It is a result of the clear dominance of Prasiola crispa in the assemblages, which, in places in the direct vicinity of the bird colonies, covers up to $100 \%$ of the surface. The role of the other species is marginal.

\section{Similarity between research areas - hierarchical-accumulative classifica-} tion. - In order to determine the similarities between the habitats regarding the occurring species a numeric hierarchical-accumulative classification was conducted.

The dendrogram showing the similarities between sites (Fig. 3) has two visible clusters. The first cluster groups habitats 1-5 located on the Gnålberget cliff and site 10 located on the Ariekammen slope. The greatest similarities are found 


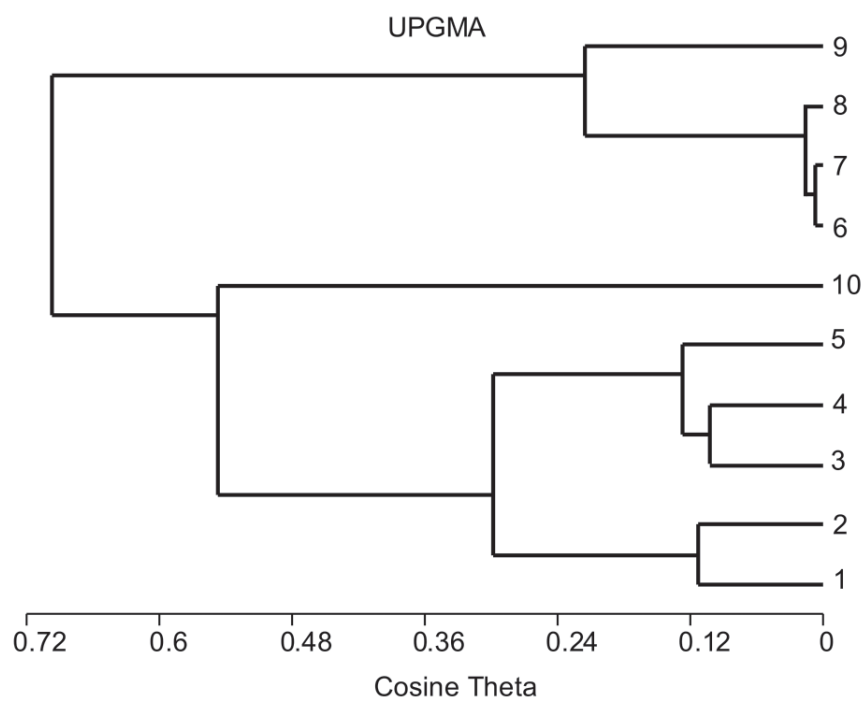

Fig 3. Hierarchical cluster Cosine Theta analysis based on the similarity of cyanobacterial and algal assemblages on the research sites (1-10).

between sites 1 and 2, which are characterized by the highest species diversity of all analyzed sites, especially with regard to coccoid cyanobacteria. Sites 3-5 had lower diversity and were dominated by Prasiola crispa and Phormidium autumnale.

Site 10 represented a slightly different phycoflora. It was located within the range of the planktivorous bird colony. However, its similarity to the group of sites under the influence of the piscivorous bird colony was determined by a similar proportion of $P$. autumnale and $P$. crispa in the assemblages.

The second cluster includes sites 6-9 located on the Ariekammen slope. The greatest similarity is found among sites 6-8, located the closest to the Alle alle colony and covered almost entirely with thalli of a single species, Prasiola crispa. Site 9 is less similar because the $P$. crispa proportion is significantly lower and the number of species forming the assemblage is considerably higher.

\section{Relationship between research areas - detrended correspondence analy-} sis. - In order to obtain information about the mutual relations between the studied sites and the related species, detrended correspondence analysis (DCA) was conducted (Fig. 4). The generated ordination diagram shows the diversity of species occurrence in relation to habitats along the gradients represented by two ordination axes. Together they constitute 53\% of total diversity, where the first axis shows $35 \%$ of diversity and the second one in terms of trophy $18 \%$. In the ordination space there are clear separate groups of cyanobacterial and algal 


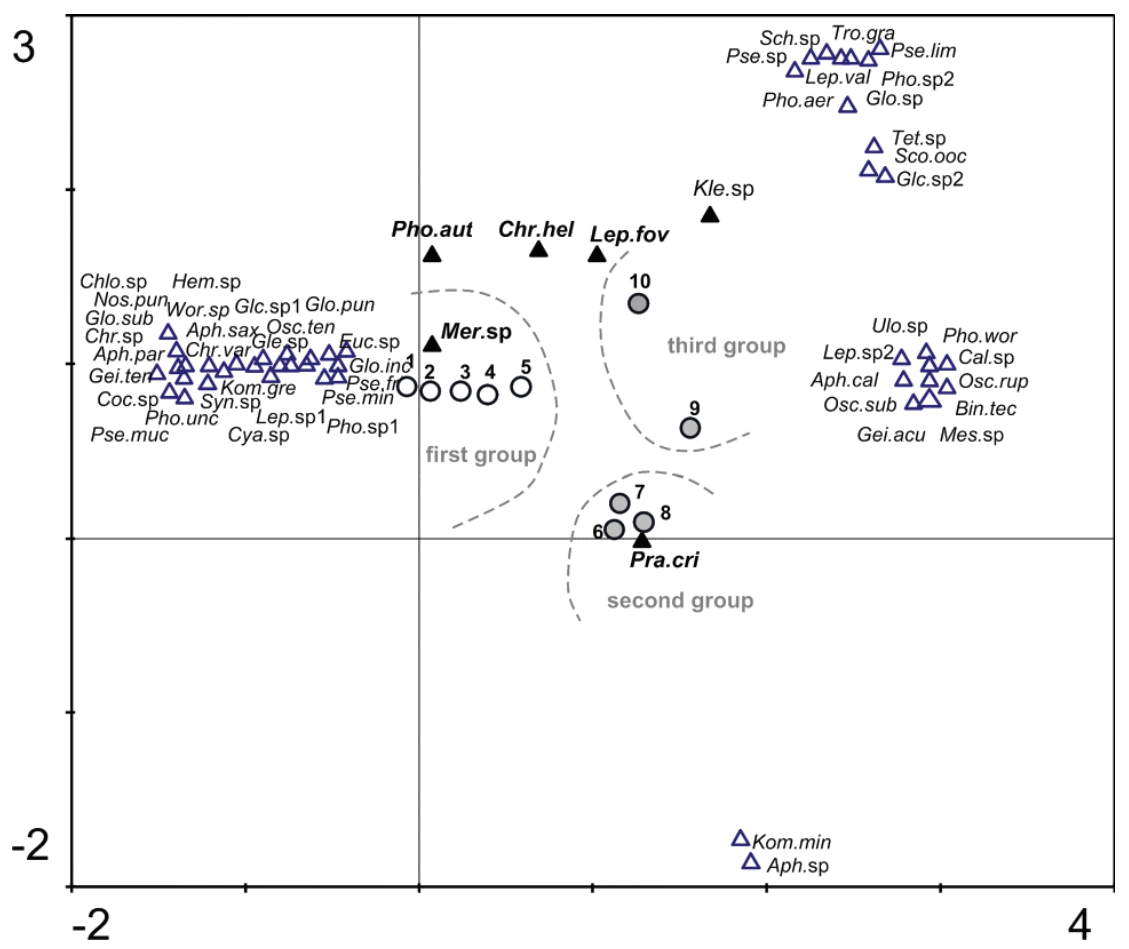

Fig 4. The results of DCA analysis; ordination diagram shows the diversity of species occurrence in relation to habitat. Black triangles show species common for all habitats, white triangles show species occurring on research sites, white circles show sites located at the foot of the Gnalberget cliff, grey circles show sites located on Ariekammen slope.

assemblages representing two types of habitats with different habitat conditions associated with the differences in the birds' diets and behavior.

The first group comprises sites located at the foot of the Gnålberget cliff (sites 1-5). Their similarity was caused by the highest species diversity of all the studied sites. Prasiola crispa, Phormidium autumnale and Merismopedia sp. had the greatest influence on the formation of the assemblages in this group. The similarity between the sites is confirmed by quantitative data (Table 1) showing that these species were the most numerous constituents of the flora. They also show an increase in the population of the species with increasing distance from the intense bird colony influence. Pseudanabaena frigida, Pseudanabaena minima, Gloeothece cf. incerta, Merismopedia sp., Gleocapsopsis sp., Phormidium sp. 1 and Eucapsis sp. also have a significant role in the shaping of the assemblages. These species reached a higher quantity and play a dominant role in the assemblages. Other species, despite a lower proportion in the assemblages, are responsible for the distinctiveness of these habitats. 
The second group comprises sites 6-8 located on the Ariekammen slope, directly under the bird nests. At such sites the dominating P. crispa had the greatest influence on formation of cyanobacterial and algal assemblages. Quantitative data show a small proportion of other species - Aphanocapsa sp., Merismopedia sp., Komvophoron minutum and P. autumnale. Those habitats had the lowest species diversity.

The third group, sites 9-10, are also located on the Ariekammen slope but under lesser influence of the planktivorous bird colonies. The group has a higher similarity to the first group, which is visible in the common species - Klebsormidium sp., Leptolyngbya foveolarum and Chroococcus helveticus. Quantitative data also confirm this group's (sites 9-10) similarity to the first group (1-5), because its assemblages had a similar proportion of $P$. crispa and $P$. autumnale. The distinctiveness of these sites is determined by species unique to them (e.g. Aphanothece caldariorum, Calothrix sp., Geitleirinema acutissima, Leptolyngbya sp. 2, Oscillatoria cf. rupicola, O. subbrevis, Pseudanabaena limnetica, Pseudanabaena sp. 2), which results in higher species diversity than in the second group.

The diagram clearly shows species common for all habitat groups. They were Prasiola crispa, Phormidium autumnale and Merismopedia sp.

\section{Discussion}

Cyanobacterial and algal ornithogenic assemblages in the Hornsund area (Spitsbergen) were formed under the influence of two seabird colonies with different diets. Nesting birds introduce nutrients to ecosystems low in nutrients, thus changing soil trophy and habitat conditions (Stempniewicz et al. 2006; Smykla et al. 2007; Jakubas et al. 2008; Huang et al. 2014; Zwolnicki et al. 2015). This, in turn, causes changes in the quantity and mass of vascular plant communities and cyanobacterial and algal assemblages in the vicinity of nesting locations (Elvebakk 1994; Matuła et al. 2007; Zmudczyńska et al. 2009; Richter et al. 2009; Kolb et al. 2010; Ellis et al. 2011; Mulder et al. 2011; Richter et al. 2014, 2015a, b; Wojciechowska et al. 2015; Zmudczyńska-Skarbek et al. 2015a, b).

The conducted analyses have shown that both bird colonies nesting in the Hornsund area and differing in diet and behavior (Jakubas et al. 2008) influenced the formation of two habitat types characterized by different cyanobacterial and algal assemblages. At all sites located on the Gnålberget cliff, which is under the influence of Uria lomvia and Rissa tridactyla (piscivorous seabirds), cyanobacterial and algal assemblages had high species richness. Such rich phycoflora was a result of higher humidity than in the sites within the Alle alle (planktivorous seabird) colony, no direct treading by birds and a very high level of phosphorus in 
the soil (Zwolicki et al. 2013). Phosphorus is an element essential for vegetation because of its role in biochemical processes. Its deficiency in the environment is a factor limiting primary production and increased $\mathrm{P}$ availability may lead to greater species diversity (Smil 2000; Elster et al. 2007; Madan et al. 2007).

The habitats located the closest to piscivorous seabirds colonies, where phosphorus reached a very high concentration (Zwolicki et al. 2013), were richer in filamentous and coccoid cyanobacteria and green algae. Pseudanabaena frigida, which has a broad spectrum of occurrence in terms of trophy levels and humidity, but prefers locations with higher nutrient values, had a particularly large proportion in the assemblage. The diversity of assemblages in these habitats was to a large extent influenced by numerous Synechococcales species. Earlier research from polar regions has shown that it is morphologically a very diverse group. Its representatives increase the biodiversity of Arctic tundra by colonizing ecological niches (Komárek 2013, 2014; Gama et al. 2014). These habitats also differed due to the presence of coccal green algae such as Gloeocystis sp. 1, Coccomyxa sp., and Chlorella sp. Species of these genera also occurred in an Antarctic area under the influence of Adélie penguin colonies (Cavacini 2001). Therefore, it may be assumed that habitats formed under the influence of piscivorous bird colonies are suitable for them.

The characteristics of the habitats located at the foot of the Gnålberget cliff also influenced the quantitative proportion and size of thalli of two species significant for eutrophic habitats - Prasiola crispa and Phormidium autumnale. Both P. crispa and P. autumnale increased their proportion in the habitat in the direction of places more distant to Uria lomvia and Rissa tridactyla colonies. Phormidium autumnale is a species with a wide spectrum of occurrence in polar regions (Komárek et al. 2008; Strunecký et al. 2010) and prefers sites with higher nitrogen concentrations but does not occur in sites with high phosphorus concentrations (Heath et al. 2014; Brasell et al. 2015). Similarly, Prasiola crispa is a typical species in cold-temperate regions, where it is usually associated with habitats rich in organic nitrogen (Graeve et al. 2002; Holzinger et al. 2006; Matuła et al. 2007; Richter et al. 2009; Broady et al. 2012; Richter et al. 2014, 2015).

Planktivorous bird colonies (Alle alle) influenced the formation of ornithogenic habitats with different habitat conditions both in trophy and the intensity of bird influence. This resulted in the formation of cyanobacterial and algal assemblages with different species compositions and different quantitative proportions of species. At sites located in the direct vicinity of the colony the assemblages were not rich. The intense interference of birds associated with their behaviour leads to the treading of places near the nests. Consequently, there is a habitat lacking mosses and vascular plants, which, in turn, exposes the soil to drying, freezing and thawing. In such conditions, lacking any competition 
such as mosses or vascular plants, Prasiola crispa dominated, with a very small number of other species (3-5), forming large, widespread thalli covering almost $100 \%$ of the surface. The dominance of this species is connected with the characteristics of the habitat formed under a very specific diet of the nesting birds, which introduce large amounts of nitrogen to the soil. P. crispa is an indicator species for nitrophilous ecosystems (Pizzaro et al. 1996; Lud et al. 2001; Raven and Taylor 2003; Wojtuń et al. 2013; Szymański et al. 2013). The thalli of Prasiola crispa in the habitat had a monostromatic lamellar, cracked form, which is probably a result of unfavorable habitat conditions caused by constant treading by birds and the risk of drying out.

At sites distant from the planktivorous bird colonies habitat conditions changed due to the limited interference from birds and the emergence of vascular plants and mosses (Chrysosplenium tetrandrum-Cochlearia groenlandica communities) (Olech 1990). The increased proportion of Phormidium autumnale in the assemblage means that the humidity of the soil increased, creating optimal conditions for this species (Matuła et al. 2007; Richter et al. 2014, 2015). All these factors led to the formation of an assemblage rich in cyanobacteria and algae. The quantity of filamentous cyanobacteria and green algae not recorded at previous sites increased.

Cyanobacterial and algal assemblages of both studied ornithogenic habitats had a similar number of species but differed significantly in qualitative composition. The difference is confirmed by the presence of only six common species out of the 55 identified ones. The species recorded in both ornithogenic habitats are widespread and often recorded in polar regions (Elster et al. 2008; Komárek and Elster 2008; Komárek 2013, 2014).

\section{Conclusions}

The obtained results confirmed that both seabird colonies nesting in the Hornsund area, differing in diet and behavior, influence the different habitat conditions in the Arctic tundra. Cyanobacteria and algae in both ornithogenic habitats respond by forming assemblages differing in quantity and quality. It is associated with the particular preferences of individual species. The difference between the habitats is also visible in the small number of common species, which further distinguish the habitats with regard to the quantitative representation in the assemblages.

The cyanobacterial and algal assemblages of the studied habitats react differently to the intensity of the bird colonies' influence. The assemblages located directly under the piscivorous birds' nests were characterized by the highest number of species, which decreased the farther from the colony it was. Cyano- 
bacterial and algal assemblages located in the direct vicinity of the planktivorous bird colonies were species poor, but the species richness increased at sites more distant from the colony's influence.

\section{References}

Anderson W.B. and Polis G.A. 1999. Nutrient fluxes from water to land: seabirds affect plant nutrient status on Gulf of California islands. Oecologia 118: 324-332.

BOKHORS S., HuISKES A., CONVEY P. and AERTS R. 2007. External nutrient inputs into terrestrial ecosystems of the Falkland Islands and the Maritime Antarctic region. Polar Biology 30: $1315-1321$.

BRAAK C.J.F. and ŠMILAUER P. 2002. CANOCO Reference Manual and CanoDraw for Windows User's Guide: Software for Canonical Community Ordination (version 4.5). Microcomputer Power (Ithaca NY, USA): 500 pp.

Brasell K., HeATH M., RYAN K.G. and WoOD S.A. 2015. Successional Change in Microbial Communities of Benthic Phormidium-Dominated Biofilms. Microbial Ecology 69: 254.

BREUNING-MADSEN H., BLOCH E.C. and BorGGAARD O.K. 2008. The impact of perennial cormorant colonies on soil phosphorus status. Geoderma 148: 51-54.

Broady P.A., Flint E.A., Nelson W.A., Cassie Cooper V., De Winton M.D. and Novis P.M. 2012. Phyla Chlorophyta and Charophyta: green algae. In: D.P. Gordon (eds) New Zealand inventory of biodiversity. Vol. 3. Kingdoms Bacteria, Protozoa, Chromista, Plantae, Fungi. Canterbury University Press, Christchurch: 347-381.

CAVACINI P. 2001. Soil algae from northern Victoria land (Antarctica). Polar Bioscience 14: 45-60.

CRAGG R.G. and BARDGETT R.D. 2001. How changes in soil faunal diversity and composition within a trophic group influence decomposition processes. Soil Biology and Biochemistry. 33: 2073-2081.

DAVEY M.C. and ROTHERY P. 1992. Factors causing the limitation of growth of terrestrial algae in maritime Antarctica during late summer. Polar Biology 12: 595-601.

Ellis J.C., Bellingham P.J., Cameron D.A., Croll D., Kolb G.S., KuefFer C., MittelhausER G.H., SCHMIDT S., VIDAL E. and WAIT D.A. 2011. Effects of seabirds on plant communities. In: C.P.H. Mulder, W.B. Anderson, D.R. Towns and P.J. Bellingham (eds) Seabird islands. Ecology, invasion and restoration. Oxford University Press, New York: 135-176.

Elser J.J., Bracken M.E., Cleland E.E., Gruner D.S., Harpole W.S., Hillebrand H., Ngai T.J, Seabloom E.W., ShuRin J.B. and Smith J.E. 2007. Global analysis of nitrogen and phosphorus limitation of primary producers in freshwater, marine and terrestrial ecosystems. Ecology Letters 10: 1135-1142.

Elster J., Degma P., KováčiK L., Valentová L., Šramková K. and Batista Pereira A. 2008. Freezing and desiccation injury resistance in the filamentous green alga Klebsormidium from the Antarctic, Arctic and Slovakia. Biologia 63: 843-851.

ERSKine P.D., Bergstrom D.M., Schmidt S., Stewart G.R., TweEdie C.E. and SHAW J.D. 1998. Subantarctic Macquarie Island - a model ecosystem for studying animal-derived nitrogen sources using 15N natural abundance. Oecologia 117: 187-193.

ELVEBAKK A. 1994. A survey of plant associations and alliances from Svalbard. Journal of Vegetation Science 5: 791-802.

GAma JR, W.A., LAUGhinghouse H.D. and St AnNA C.L. 2014. How diverse are coccoid cyanobacteria? A case study of terrestrial habitats from the Atlantic Rainforest (Sao Paulo, Brazil). Phytotaxa 178: 61. 
GoDZIK B. 1991. Heavy metals and macroelements in the tundra of southern Spitsbergen: the effect of little auk (Alle alle) colonies. Polar Research 9: 121-131.

Graeve M., Kattner G., Wiencke C. and Karsten U. 2002. Fatty acid composition of Arctic and Antarctic macroalgae: indicator of phylogenetic and trophic relationships. Marine Ecology Progress Series 231: 67-74.

HAWKE D.J. and NEWMAN J. 2004. Inventories and elemental accumulation in peat soils of forested seabird breeding islands, southern New Zealand. Soil Research 42: 45-48.

Heath M.W., Wood S.A., Brasell K., Young R. and Ryan K.G. 2014. Development of habitat suitability criteria and in-stream habitat assessment for the benthic cyanobacteria Phormidium. River Research and Applications 31: 98-108.

HODKINSON I.D., WEBB N.R. and COULSON S.J. 2002. Primary community assembly on land the missing stages: why are the heterotrophic organisms always there first. Journal of Ecology 90: 569-577.

HolZINGER A., KARSTEN U., LÜTZ C. and WIENCKE C. 2006. Ultrastructure and photosynthesis in the supralittoral green macroalga Prasiola crispa from Spitsbergen (Norway) under UV exposure. Phycologia. 45: 168-177.

Hoek C., Mann D.G. and Jahns H.M. 1995. Algae: an Introduction to Phycology. University Press, Cambridge: 623 pp.

HoGG E.H. and MORTON J.K. 1983. The effects of nesting gulls on the vegetation and soil of islands in the Great Lakes. Canadian Journal of Botany 61: 3240-3254.

Huang T., Sun L., WANG Y., Chu Z., QIN X. and YANG L. 2014. Transport of nutrients and contaminants from ocean to island by emperor penguins from Amanda Bay, East Antarctic. Science of the Total Environment 468: 578-583.

JAKUBAS D., ZMUDCZYŃSKA K., WoJCZULANIS-JAKUBAS K. and STEMPNIEWICZ L. 2008. Faeces deposition and numbers of vertebrate herbivores in the vicinity of planktivorous and piscivorous seabird colonies in Hornsund, Spitsbergen. Polish Polar Research 29: 45-58.

KAŠTOVSKA K., ElSTER J., STIBAL M. and ŠĂNTRŮČKOVÁ H. 2005. Microbial Assemblages in Soil Microbial Succession After Glacial Retreat in Svalbard (High Arctic) Microbial Ecology 50: 396-407.

KolB G.S., EKHOLM J. and HAMBÄCK P.A. 2010. Effects of seabird nesting colonies on algae and aquatic invertebrates in coastal waters. Marine Ecology Progress Series 417: 287-300.

KOMÁREK J. 2013. Phenotypic and ecological diversity of freshwater coccoid cyanobacteria from maritime Antarctica and islands of NW Weddell Sea. I. Synechococcales. Czech Polar Reports 3: $130-143$.

KoMÁREK J. 2014. Phenotypic and ecological diversity of freshwater coccoid cyanobacteria from maritime Antarctica and Islands of NW Weddell Sea. II. Czech Polar Reports 4: 17-39.

KOMÁREK J. 2016. Review of the cyanobacterial genera implying planktic species after recent taxonomic revisions according to polyphasic methods: state as of 2014. Hydrobiologia 764: $259-270$.

KOMÁREK J. and ElSTER J. 2008. Ecological background of cyanobacterial assemblages of the northern part of James Ross Island, Antarctica. Polish Polar Research 29: 17-32.

KOMÁREK J., ElSTER J. and KOMÁREK O. 2008. Diversity of cyanobacterial microflora of the northern part of James Ross Island, NW Weddell Sea, Antarctica. Polar Biology 31: 853-865.

KOVACH W.L. 1985-1999. MVSP PLUS version 3.1. Pentraeth, UK

LAN S., Wu L., ZHANG D. and Hu CH. 2013. Assessing Level of Development and Successional Stages in Biological Soil Crusts with Biological Indicators. Microbial Ecology 66: 394-403. 
LigęZA S. and Smal H. 2003. Accumulation of nutrients in soils affected by perennial colonies of piscivorous birds with reference to biogeochemical cycles of elements. Chemosphere 52: 595-602.

LINDEBOOM H.J. 1984. The nitrogen pathway in a penguin rookery. Ecology 65: 269-277.

Lud D., Buma A.G., VAN DE Poll W., MoerdiJK T.C. and HuisKes A.H. 2001. DNA damage and photosynthetic performance in the Antarctic terrestrial alga Prasiola crispa spp. antarctica (Chlorophyta) under manipulated UV-B radiation. Journal of Phycology 34: 459-467.

MADAN N.J., DEACON L.J. and ROBINSON C.H. 2007. Greater nitrogen and/or phosphorus availability increase plant species' cover and diversity at a High Arctic polar semidesert. Polar Biology 30: 559-570.

MatuŁa J., Pietryka M., Richter D. and Wojtuń B. 2007. Cyanobacteria and algae of Arctic terrestrial ecosystems in the Hornsund area, Spitsbergen. Polish Polar Research 28: 283-315.

Mulder C.P.H., Jones H., Kameda K., Palmborg C., Schmidt S., Ellis J.C., OrRock J.L., Wait D.A., Wardle D.A., YAng L., Young H., Croll D. and Vidal E. 2011. Impacts of seabirds on plant and soil properties. In: C.P.H. Mulder, W.B. Anderson, D.R. Towns, P.J. Bellingham (eds) Seabird islands. Ecology, invasion and restoration. Oxford University Press, New York: $135-176$.

MYRCHA A. and TATUR A. 1991. Ecological role of the current and abandoned penguin rookeries in the land environment of the maritime Antarctic. Polish Polar Research 12: 3-24.

ODASZ A.M. 1994. Nitrate reductase activity in vegetation below an arctic bird cliff, Svalbard, Norway. Journal of Vegetation Science 5: 913-920.

Olech M. 1990. Preliminary studies on ornitocoprophilous lichens of the Arctic and Antarctic regions. Proceedings of the NIPR Symposium on Polar Biology, Tokyo. 3: 218-223.

Pennings S.C., Clark C.M., Cleland E.E., Collins S.L., Gough L., Gross K.L., MilchuNAS D. and SUDING K.N. 2005. Do individual plant species show predictable responses to nitrogen addition across multiple experiments? Oikos 110: 547-555.

PizZARo H., IZAGUiRRe I. and TELl G. 1996. Epilithic algae from a freshwater stream at Hope Bay, Antarctica. Antarctic Science 8: 161-167.

RAVEN J.A. and TAYLOR R. 2003. Macroalgal growth in nutrient-enriched estuaries: a biogeochemical and evolutionary perspective. Water, Air and Soil Pollution: Focus 3: 7-26.

Richter D., MATUŁA J. and PIETRYKA M. 2009. Cyanobacteria and algae of selected habitats in tundra around Hornsund fiord (West Spitsbergen). Oceanology and Hydrobiology Studies 38: 1-6.

Richter D., PietryKa M. and MatuŁA J. 2014. The diversity of cyanobacteria and green algae on ecological different types of vegetation in Horsund area (West Spitsbergen, Svalbard). In: Migała K., Owczarek P., Kasprzak M. and Strzelecki M. (eds) New perspectives in polar research. University of Wrocław: 137-162.

Richter D., PietryKa M. and MatuŁA J. 2015. Relationship of cyanobacteral and algal assemblages with vegetation in the high Arctic tundra (West Spitsbergen, Svalbard Archipelago). Polish Polar Research 36: 239-260.

RYAN P.G. and WATKINS B.P. 1989. The influence of physical factors and ornithogenic products on plant and arthropod abundance at an inland nunatak group in Antarctica. Polar Biology 10: $151-160$.

SKrZYPeK G., Wojtuń B., Richter D., JAKubas D., WojcZulanis-JaKubas K. and SAMECKA-CYMERMAN A. 2015. Diversification of Nitrogen Sources in Various Tundra Vegetation Types in the High Arctic. PLoS ONE: 10(9): e0136536.

SHANNON C.E. and WEAVER W. 1949. The Mathematical Theory of Communication. University of Illinois Press. Urbana, IL, USA: 117 pp. 
SMIL V. 2000. Phosphorus in the environment: natural flows and human interferences. Annual Review of Energy and the Environment 25: 53-88.

SMith V.R. and Froneman P.W. 2008. Nutrient dynamics in the vicinity of the Prince Edward Islands. The prince Edward Islands. Land-sea interactions in a changing ecosystem. SUN Press, Stellenbosch: 165-179.

SMYKLA J., WOLEK J. and BARCIKOWSKI A. 2007. Zonation of vegetation related to penguin rookeries on King George Island, Maritime Antarctic. Arctic, Antarctic, and Alpine Research 39: $143-151$.

STATSOFT, INC. 2014. STATISTICA (data analysis software system), version 12. www.statsoft.com

STEMPNIEWICZ L. 1990. Biomass of dovekie excreta in the vicinity of a breeding colony. Colonial Waterbird 13: 62-66.

STEMPNIEWICZ L. and WĘSŁAWSKI J.M. 1992. Outline of trophic relationships in Hornsund fjord, SW Spitsbergen with special consideration of seabirds, In: K.W. Opaliński and R.Z Klekowski, Landscape, life world and man in the high Arctic. Instytut Ekologii PAN, Warszawa: 271-298.

STEMPNIEWICZ L. 2005. Keystone species and ecosystem functioning. Seabirds in polar ecosystems. Ecology Quest 6: 111-115.

STEMPNIEWICZ L., ZWOLNICKI A., ILISZKo L., ZMUdCZYŃSKA K., WOJTUŃ B. and MATUŁA J. 2006. Impact of plankton- and fish-eating seabird colonies on the Arctic tundra ecosystem - a comparison. Journal of Ornithology 147: 257-258.

StempNiEWICZ L., BŁACHOWIAK-SAMOŁYK K. and WęSŁAWSKi J.M. 2007. Impact of climate change on zooplankton communities, seabird populations and Arctic terrestrial ecosystema scenario. Deep Sea Research Part II: Topical Studies in Oceanography 54: 2934-2945.

STRUNECKÝ O., ElSTER J. and KOMÁREK J. 2010. Phylogenetic relationships between geographically separate Phormidium cyanobacteria: is there a link between north and south polar regions? Polar Biology 33: 1419-1428.

SZYMAŃSKI W., SKIBA S. and WOJTUŃ B. 2013. Distribution, genesis, and properties of Arctic soils: a case study from the Fuglebekken catchment, Spitsbergen. Polish Polar Research 34: 289-304.

TATUR A. 2002. Ornithogenic ecosystems in the maritime Antarctic-formation, development and disintegration. In: Geoecology of Antarctic Ice-Free Coastal Landscapes. Springer, Berlin, Heidelberg: $161-184$.

THEOdosE T.A. and BowMAN W.D. 1997. Nutrient availability, plant abundance, and species diversity in two alpine tundra communities. Ecology 78: 1861-1872.

Wojciechowska A., Zwolicki A., BARCiKOWski A. and StempNiEwicZ L. 2015. The structure of Cochlearia groenlandica population along the bird colony influence gradient (Hornsund, Spitsbergen). Polar Biology 38: 1919-1930.

WoJTuń B., SAMECKA-CYMERMAn A., KolOn K., KemPERS A.J. and SKRZYPEK G. 2013. Metals in some dominant vascular plants, mosses, lichens, algae, and the biological soil crust in various types of terrestrial tundra, SW Spitsbergen, Norway. Polar Biology 36: 1799-1809.

ZELENSKAYA L.A. and KHOREVA M.G. 2006. Growth of the nesting colony of slaty-backed gulls (Larus schistisagus) and plant cover degradation on Shelikan Island (Taui Inlet, the Sea of Okhotsk). Russian Journal of Ecology 37: 126-134.

ZIÓŁEK M. and MELKE J. 2014. The impact of seabirds on the content of various forms of phosphorus in organic soils of the Bellsund coast, western Spitsbergen. Polar Research 33: doi: http:// dx.doi.org/10.3402/polar.v33.19986

ZMUDCZYŃSKA K., ZWOLICKI A., BARCIKOWSKI M., BARCIKOWSKI A., and STEMPNIEWICZ L. 2009. Spectral characteristics of the Arctic ornithogenic tundra vegetation in Hornsund area, SW Spitsbergen. Polish Polar Research 30: 249-262. 
Zmudczyńska K., OlejnicZak I., Zwolicki A., Iliszko L., Convey P. and StemPNiewicz L. 2012. Influence of allochtonous nutrients delivered by colonial seabirds on soil collembolan communities on Spitsbergen. Polar Biology 35: 1233-1245.

ZMUDCZYŃSKA-SKARBEK K., BALAZY P. and KUKLIŃSKI P. 2015. An assessment of seabird influence on Arctic coastal benthic communities. Journal of Marine Systems 144: 48-56.

ZMUdCZYŃSKA-SKARBEK K., ZWOLICKI A., CONVEY P., BARCIKOWSKI M. and STEMPNIEWICZ L. 2015. Is ornithogenic fertilisation important for collembolan communities in Arctic terrestrial ecosystems? Polar Research. 34: doi: http://dx.doi.org/10.3402/polar.v34.25629.

Zwolicki A., ZMudCZYŃSKa-SKarbeK K.M., IlisZKo L. and SteMPNIEWICZ, L. 2013. Guano deposition and nutrient enrichment in the vicinity of planktivorous and piscivorous seabird colonies in Spitsbergen. Polar Biology 36: 363-372.

Zwolicki A., BARCikowski M., BARCIKOWSKi A., CYMERSKi M., STEMPNIEWICZ L. and CoNVEY P. 2015. Seabird colony effects on soil properties and vegetation zonation patterns on King George Island, Maritime Antarctic. Polar Biology 38: 1645-1655.

Received 2 March 2016

Accepted 23 April 2016 